\title{
Hubungan Antara Kadar Hemoglobin dan Status Gizi dengan Produktivitas Pekerja Wanita di Bagian Percetakan dan Pengemasan di UD X Sidoarjo
}

\author{
Correlation between Hemoglobin Level, Nutritional Status and Women \\ Employee Productivity in Stamping and Packaging Section at UD X Sidoarjo
}

Uswatun Khasanah*1, Triska Susila Nindya ${ }^{1}$

\begin{abstract}
ABSTRAK
Latar Belakang: Produktivitas kerja menjadi hal utama yang harus dimiliki setiap tenaga kerja untuk menghasilkan produk. Banyak faktor yang dapat mempengaruhi produktivitas kerja seperti status gizi dan anemia. Anemia merupakan masalah gizi yang dapat menyebabkan kelelahan dan penurunan kapasitas kerja serta produktifitas pada tenaga kerja.

Tujuan: Penelitian ini bertujuan untuk menganalisis hubungan antara status gizi dan kadar hemoglobin dengan produktivitas pekerja wanita bagian percetakan dan pengemasan di UD $X$ Sidoarjo.

Metode: Jenis penelitian yang dilakukan merupakan observasional analitik dengan menggunakan pendekatan cross sectional. Populasi pada penelitian ini merupakan semua pekerja wanita di bagian produksi sebanyak 130 orang dan didapatkan besar sampel sebanyak 54 responden yang dipilih secara random sampling. Teknik pengumpulan data menggunakan pengukuran tinggi dan berat badan, pengukuran kadar hemoglobin, dan kuesioner. Analisis data menggunakan uji chi square.

Hasil: Penelitian menunjukkan bahwa responden cenderung memiliki produktivitas diatas rata-rata. Terdapat hubungan antara status gizi dengan produktivitas $(p=0,014)$, namun tidak terdapat hubungan antara kadar hemoglobin dengan produktivitas $(p=0,836)$.

Kesimpulan: Semakin baik status gizi semakin meningkat produktivitasnya. Tidak ada hubungan antara kadar $\mathrm{Hb}$ dengan produktivitas. Dianjurkan agar pegawai wanita perusahaan menyadari status gizi mereka.
\end{abstract}

Kata Kunci: produktivitas, pekerja wanita, kadar hemoglobin, status gizi 


\section{ABSTRACT}

Background : Work produvtivity is the top priority demanded of every workforce to produce the product. Many factors can affect work produktivity such as nutritional status and anemia. Anemia is a nutritional problem that can cause fatigue, weakness, loss of work capacity and produktivity.

Objective: The purpose of this research was to analyze the relation between hemoglobin levels and nutritional status with women employee's produktivity in stamping and packaging section at UD $X$ Sidoarjo.

Methods: This reserch was an observational analytic study designed with cross sectional. The population was all women employees in production of 130 people and the sample of 54 respondents selected by random sampling. Data collection used height and weight measurement, measurement of hemoglobin levels, and questionnaires. Data were analyzed using chi square test.

Results: The result showed that there was a correlation between the nutritional status and productivity $(p=0.014)$, but there was no correlation between $\mathrm{Hb}$ concentration and productivity ( $p=0.836)$.

Conclusion: The better the nutritional status were, the higher the productivity would be. It is recommended that the women employees of this company to aware on their nutritional status.

Keywords: productivity, women employees, hemoglobin levels, nutritional status

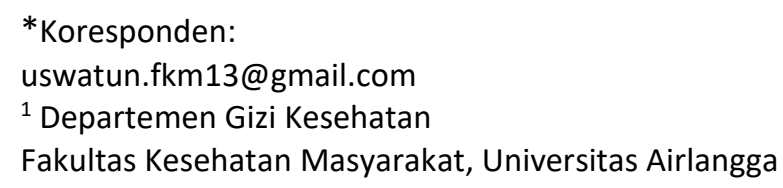

\section{PENDAHULUAN}

Banyaknya masalah kesehatan yang terjadi pada tenaga kerja khususnya penyakit akibat kerja di Indonesia terdapat 40.694 kasus pada tahun $2014^{1}$. Masalah kesehatan tersebut diakibatkan oleh stres akibat bekerja, gangguan kesehatan akibat faktor ergonomi, gangguan kesehatan reproduksi dan masalah gizi². Salah satu masalah yang dapat mempengaruhi produktivitas kerja terkait dengan kesehatan dan gizi terutama pada pekerja wanita adalah anemia gizi ${ }^{3}$. Hasil pengamatan riset kesehatan dasar menunjukkan pada tahun 2007 hingga tahun 2013 prevalensi anemia penduduk perempuan (15-54 tahun) di Indonesia yaitu $19,7 \%$ di tahun 2007 dan meningkat sebesar 23,9\% di tahun $2013^{4}$.

Kadar hemoglobin dapat digunakan sebagai parameter yang menandakan keadaan anemia zat besi ${ }^{5}$. Anemia zat besi ditandai dengan kadar hemoglobin di bawah nilai normal $12,0 \mathrm{mg} / \mathrm{dl}$ pada perempuan dewasa ${ }^{6}$. Kelompok yang rentan terhadap anemia zat besi adalah tenaga kerja wanita. Kurangnya asupan zat gizi merupakan faktor yang mengakibatkan terjadinya anemia pada pekerja wanita, selain itu menstruasi yang dialami wanita usia subur setiap bulan juga berpengaruh terhadap kadar hemoglobin dan produktivitas pada pekerja ${ }^{7}$. Anemia yang terjadi pada Wanita Usia Subur (WUS) dapat menimbulkan dampak bagi kesehatan dan performa kerja seperti kelelahan dan penurunan kapasitas kerja. Wanita dengan keadaan anemia, produktivitasnya lebih rendah jika dibandingkan dengan wanita yang tidak anemia karena dapat terjadi penurunan kapasitas kerja pada penderita anemia, artinya semakin rendah kadar hemoglobin maka akan menurunya produktivitas kerja ${ }^{8}$.

Status gizi pada pekerja memiliki fungsi penting bagi kesejahteraan atau dalam hal meningkatkan keterampilan dan produktivitas. Status gizi menggambarkan suatu kondisi tubuh yang dihasilkan oleh keseimbangan 
antara kebutuhan gizi dengan asupan zat gizi yang dipengaruhi oleh konsumsi makanan dan penggunaan zat-zat di dalam tubuh ${ }^{9}$. Keadaan gizi dapat ditentukan dari konsumsi makan seseorang. Tingkat asupan gizi penting bagi tenaga kerja karena sebagai penilaian kualitas produktivitas kerjanya ${ }^{10}$. Pada pekerja dengan status gizi normal lebih memiliki produktivitas dengan terkategori baik ${ }^{11}$. Status gizi yang tidak normal (kurus atau gemuk) pada tenaga kerja, meskipun persentase yang ditemukan tidak besar tetapi perlu mendapat perhatian ${ }^{12}$. Hal tersebut dapat menunjukkan bahwa kesehatan dan produktivitas pada tenaga kerja erat korelasinya dengan status gizi ${ }^{13}$. Konsumsi pangan yang beragam dan seimbang serta peningkatan status gizi yang sesuai merupakan faktor penting dalam meningkatkan kualitas hidup manusia dan akan sangat berpengaruh pada produktivitas pekerja $^{14}$

UD $X$ merupakan industri yang memproduksi krupuk mentah. Mayoritas pekerja pada UD $\mathrm{X}$ adalah wanita, yaitu sebanyak $65 \%$ dari total keseluruhan sebanyak 200 pekerja. Pada bagian percetakan dan pengemasan krupuk merupakan bagian yang seluruhnya dikerjakan oleh pekerja wanita yang merupakan salah satu kelompok yang rentan terhadap anemia. Tujuan dari penelitian ini adalah untuk menganalisis hubungan antara status gizi dan kadar hemoglobin dengan produktivitas pekerja wanita bagian percetakan dan pengemasan di UD X Sidoarjo.

\section{METODE}

Bentuk penelitian ini adalah observasional analitik yang menggunakan desain cross sectional. Besar populasi dalam penelitian ini adalah 130 orang yang merupakan pekerja wanita pada bagian produksi di UD X. Besar sampel didapatkan dari perhitungan rumus simple random sampling yaitu sebesar 54 pekerja wanita. Responden yang menjadi sampel penelitian ini harus sesuai dengan kriteria inklusi yaitu pekerja wanita yang tidak sedang menstruasi, tidak sedang hamil, tidak sedang menyusui bayi dan bersedia menjadi responden.
Penelitian dilakukan di UD X Desa Tropodo Kecamatan Krian Kabupaten Sidoarjo pada bulan September hingga Oktober 2017.

Data yang dikumpulkan terdiri dari data primer dan data sekunder dengan menggunakan teknik wawancara, teknik pengukuran dan observasi/pengamatan. Teknik wawancara dilakukan untuk mengetahui karakteristik pekerja dengan bantuan kuisioner. Teknik pengukuran untuk mengetahui tinggi badan, berat badan dan kadar hemoglobin. Pengukuran TB dan BB untuk mengetahui status gizi. kategori status gizi bedasarkan IMT yang digunakan menurut Kemenkes RI, 2011 yaitu kurus $\left(<18,4 \mathrm{~kg} / \mathrm{m}^{2}\right)$, normal $\left(18,5-25,0 \mathrm{~kg} / \mathrm{m}^{2}\right)$, gemuk $(25,1-27,0$ $\left.\mathrm{kg} / \mathrm{m}^{2}\right)$ dan sangat gemuk $\left(\geq 27,1 \mathrm{~kg} / \mathrm{m}^{2}\right)$. Sedangkan observasi dilakukan untuk mendapatkan data produktivitas pekerja dalam kurun waktu tertentu. Instrumen pengumpulan data yang digunakan adalah form kuisioner, alat ukur tinggi badan (microtoise) dan berat badan (digital scale), perlengkapan pengukuran kadar hemoglobin dengan metode cyanmethemoglobin dan lembar observasi untuk mengumpulkan data produktivitas. Pengukuran produktivitas merupakan hasil produk yang dihasilkan lebih banyak oleh tenaga kerja dibandingkan dengan rata-rata hasil produksi dalam satuan waktu yang sama ${ }^{15}$. Pada penelitian ini kategori untuk menentukan produktivitas dalam 8 jam kerja adalah $<83,4 \mathrm{~kg}$ (dibawah rata-rata), $\geq 83,4 \mathrm{~kg}$ (diatas rata-rata) untuk bagian percetakan kerupuk. Sedangkan untuk kategori bagian pengemasan kerupuk adalah $<166 \mathrm{~kg}$ (dibawah rata-rata) dan $\geq 166 \mathrm{~kg}$ (diatas rata-rata). Hubungan antar variabel pada penelitian ini menggunakan uji chi square dengan taraf signifikansi sebesar $95 \%$.

\section{HASIL DAN PEMBAHASAN}

Produktivitas merupakan prioritas utama yang dituntut dari setiap tenaga kerja untuk dapat menghasilkan produk. Seorang tenaga kerja dikatakan produktif jika ia mampu menghasilkan keluaran (output) yang lebih banyak dari tenaga kerja lain untuk satuan waktu yang sama ${ }^{16}$. Kadar hemoglobin merupakan faktor yang yang dapat 
Tabel 1. Distribusi karakteristik Pekerja Wanita Bagian percetakan dan pengemasan di UD X Sidoarjo

\begin{tabular}{lcc}
\hline Karakteristik & $\mathbf{n ~ ( 5 4 )}$ & $\mathbf{\%}$ \\
\hline Usia (Tahun) & & \\
$19-29$ & 5 & 9,3 \\
$30-49$ & 47 & 87,0 \\
$50-64$ & 2 & 3,7 \\
\hline Tingkat Pendidikan & & \\
SD/Sederajat & 5 & 9,3 \\
SMP/Sederajat & 46 & 85,1 \\
SMA/Sederajat & 3 & 5,5 \\
\hline Lama Kerja & & \\
1 tahun & 6 & 11,1 \\
2 tahun & 12 & 22,2 \\
3 tahun & 16 & 29,6 \\
4 tahun & 14 & 25,9 \\
5 tahun & 6 & 11,1 \\
\hline
\end{tabular}

mempengaruhi tinggi rendahnya produktivitas kerja. Batas kadar hemoglobin normal bedasarkan wanita dewasa adalah $12,0 \mathrm{mg} / \mathrm{dl}$ ${ }^{6}$. Jika terjadi kekurangan kadar hemoglobin dapat mengakibatkan anemia sehingga aktivitas tubuh terutama daya berfikir akan menurun ${ }^{17}$. Selain itu, status gizi juga dapat mempengaruhi produktivitas kerja. Status gizi yang optimal terjadi bila tubuh mendapatkan cukup zat-zat gizi yang digunakan secara efisien sehingga memungkinkan meningkatnya kemampuan kerja dan kesehatan ${ }^{18}$.
Karakteristik pekerja wanita pada tabel 1 menunjukkan bahwa mayoritas usia pekerja wanita berada pada kategori usia 30-49 tahun (87\%). Secara fisik seseorang yang terkategori usia produktif memiliki kemampuan untuk bekerja yang lebih baik dibandingkan dengan usia tidak produktif. Seiring dengan bertambahnya usia, kemampuan seseorang akan menurun khususnya dalam fungsi fisiologis tubuh sehingga kekuatan fisik tidak sebaik waktu masih muda ${ }^{19}$. Tingkat pendidikan pekerja wanita sebagian besar adalah tamat SMP/Sederajat sebanyak $85,1 \%$. Bedasarkan hasil wawancara tidak ada syarat maksimal tingkat pendidikan yang ditempuh untuk penerimaan karyawan baru. Sehingga hasil tersebut menunjukkan bahwa mayoritas pendidikan pekerja wanita tergolong cukup

Tabel 2. Distribusi Kadar Hemoglobin dan Status Gizi Pekerja Wanita Bagian Percetakan dan Pengemasan

\begin{tabular}{lcc}
\hline \multicolumn{1}{c}{ Variabel } & $\mathbf{n}(\mathbf{5 4 )}$ & $\mathbf{\%}$ \\
\hline Kadar Hemoglobin & & \\
$\mathrm{Hb}<12 \mathrm{mg} / \mathrm{dl}$ & 23 & 42,6 \\
$\mathrm{Hb} \geq 12 \mathrm{mg} / \mathrm{dl}$ & 31 & 57,4 \\
\hline Status Gizi & & \\
Normal & 31 & 57,4 \\
Gemuk & 6 & 11,1 \\
Sangat gemuk & 17 & 31,5 \\
\hline
\end{tabular}

Tabel 3. Hubungan Antara Nilai Kadar Hemoglobin dengan Produktivitas Pekerja Wanita Bagian Percetakan dan pengemasan di UD X Sidoarjo

\begin{tabular}{lccccc}
\hline \multirow{3}{*}{ Kadar Hemoglobin } & \multicolumn{4}{c}{ Produktivitas Kerja } & \multirow{2}{*}{ P value } \\
\cline { 2 - 5 } & \multicolumn{2}{c}{ Diatas rata-rata } & \multicolumn{2}{c}{ Dibawah rata-rata } & \\
\cline { 2 - 5 } & $\mathbf{n}$ & $\mathbf{\%}$ & $\mathbf{n}$ & $\mathbf{\%}$ & \\
\hline $\mathrm{Hb}<12 \mathrm{mg} / \mathrm{dl}$ & 14 & 60,9 & 9 & 39,1 & \multirow{2}{*}{0,836} \\
$\mathrm{Hb} \geq 12 \mathrm{mg} / \mathrm{dl}$ & 18 & 58,1 & 13 & 41,9 & \\
\hline
\end{tabular}

Tabel 4. Hubungan Antara Status Gizi dengan Produktivitas Pekerja Wanita Bagian Percetakan dan pengemasan di UD X Sidoarjo

\begin{tabular}{|c|c|c|c|c|c|}
\hline \multirow{3}{*}{ Status Gizi } & \multicolumn{4}{|c|}{ Produktivitas Kerja } & \multirow{3}{*}{ P value } \\
\hline & \multicolumn{2}{|c|}{ Diatas rata-rata } & \multicolumn{2}{|c|}{ Dibawah rata-rata } & \\
\hline & $\mathbf{n}$ & $\%$ & $\mathbf{n}$ & $\%$ & \\
\hline Normal & 14 & 45,2 & 17 & 54,8 & 0011 \\
\hline Gemuk & 18 & 78,3 & 5 & 21,7 & 0,014 \\
\hline
\end{tabular}


rendah. Secara umum dapat dikatakan bahwa kemampuan intelektual seseorang karyawan dapat dinilai dari tingkat pendidikan yang diraihnya ${ }^{20}$. Jika seorang karyawan memiliki tingkat pendidikan yang sesuai dengan pekerjaannya akan mendorong setiap karyawan dalam mencapai produktivitas kerja $^{21}$. Karakteristik responden berdasarkan lama kerja menunjukkan bahwa rata-rata pekerja wanita mempunyai masa kerja selama 3 tahun sebesar $29,6 \%$. Pekerja wanita yang masa kerjanya paling lama mengaku bahwa mereka bekerja sejak pabrik pertama kali beroperasi. Lamanya seseorang bekerja di suatu tempat akan menandakan semakin banyaknya pengalaman kerja dan kemampuan untuk menyelesaikan pekerjaanya, sehingga masa kerja dapat berpengaruh terhadap produktivitas ${ }^{22}$.

Hasil pengukuran kadar hemoglobin pekerja yang anemia (kadar $\mathrm{hb}<12 \mathrm{mg} / \mathrm{dl}$ ) sebesar 42,6\%, menurut WHO (2011) angka tersebut termasuk masalah kesehatan masyarakat degan kategori parah karena prevalensinya lebih dari $40 \%$. Hasil uji statistik pada tabel 3 menunjukkan bahwa tidak ada hubungan antara kadar hemoglobin dengan produktivitas kerja dapat dilihat dari nilai $p=$ $0,836$ ( $p>0,05)$. Hal tersebut tidak sesuai dengan penelitian yang dilakukan pada Industri Lia Garmen Boyolali, yang menyatakan bahwa ada hubungan yang signifikan kadar hemoglobin dengan produktivitas kerja pada pekerja wanita ${ }^{23}$. Tidak adanya hubungan pada penelitian ini disebabkan pekerja wanita yang mengalami anemia termasuk kategori anemia ringan hal ini ditunjukkan dengan rata-rata nilai hemoglobin responden adalah $11,8 \mathrm{mg} / \mathrm{dl}$, selain itu pada saat penelitian tidak memilih responden yang anemia dan tidak anemia secara proporsional. Pada pekerja wanita menunjukkan kecenderungan, baik itu pada pekerja yang anemia atau normal memiliki aktivitas fisik sedang pada saat bekerja. Aktivitas fisik yang dapat mempegaruhi rendahnya kadar hemoglobin adalah aktivitas fisik berat karena pada aktivitas fisik terlau berat dapat menimbulkan hemolisis ${ }^{24}$. Terjadinya hemolisis akibat kompresi pembuluh darah yang disebabkan oleh kontraksi yag kuat dari otot-otot pada aktivitas fisik yang dilakukan oleh seseorang, hal tersebut menyebabkan kehilangan zat besi akibat dari penghancuran membran sel darah merah yang akan mempengaruhi kadar hemoglobin dalam darah ${ }^{25}$. Bedasarkan penjelasan tersebut bahwa pekerja wanita dengan aktivitas sedang sebagian besar memiliki kadar hemoglobin normal, dapat dikatakan bahwa aktivitas yang dilakukan pekerja wanita adalah tidak berlebihan sehingga tidak terjadinya penurunan hemoglobin yang parah dan pekerja dapat menyelesaikan pekerjaanya. Oleh karena itu pekerja cenderung memiliki produktivitas diatas rata-rata baik itu pekerja yang anemia atau normal.

Pada penelitian ini, status gizi pekerja wanita sebagian besar memiliki status gizi normal. Akan tetapi terdapat pekerja wanita yang memiliki status gizi lebih (status gizi gemuk). Aktivitas pekerja wanita di bagian produksi, khususnya bagian percetakan dan pengemasan merupakan aktivitas sedang yang lebih banyak duduk dan mengandalkan aktivitas tangan untuk melakukan pekerjaannya. Berdasarkan hasil tabulasi silang pada tabel 4, diketahui bahwa status gizi mempunyai hubungan yang signifikan dengan produktivitas kerja dilihat dari nilai $p=$ $0,014(p<0,05)$. Penelitian ini sejalan dengan penelitian yang menunjukkan bahwa terdapat hubungan atara status gizi dengan produktivitas kerja ${ }^{21}$. Status gizi dapat dijadikan sebagai penentu kesehatan tenaga kerja dan produktivitas. Seorang pekerja akan memiliki kapasitas kerja dan daya tahan tubuh lebih baik jika keadaan gizinya normal ${ }^{26}$. Terdapatnya hubungan status gizi dengan produktivitas kerja pada penelitian ini menunjukkan bahwa semakin tinggi status gizi pekerja, produktivitasnya semakin baik. Hal ini dikarenakan pekerjaan yang dilakukan pada bagian percetakan dan pengemasan krupuk dibutuhkan kekuatan fisik yang baik untuk mengangkat beban yang cukup berat sehingga pekerja yang memiliki status gizi lebih lebih mampu menyelesaikan pekerjaannya. Status gizi dapat dipengaruhi oleh setiap jenis zat gizi dari asupan makan mempunyai fungsi utama sebagai zat tenaga, zat pembangun dan zat 
pengatur $^{18}$. Bagi tenaga kerja, kecukupan energi dan gizi seimbang merupakan penentu utama derajat produktivitas kerja ${ }^{27}$. Asupan energi serta zat gizi seimbang mempunyai peran penting dalam peningkatan ketahanan fisik, jika asupan energi meningkat akan mengakibatkan tubuh menjadi lebih aktif dan kemampuan melakukan aktivitas juga meningkat sehingga mengakibatkan peningkatan produktivitas kerja seseorang ${ }^{28}$.

\section{KESIMPULAN}

Ditinjau dari kadar hemoglobin, pekerja wanita cenderung pada kategori produktifitas diatas rata-rata baik pekerja yang anemia atau normal. Jika produktivitas ditinjau dari status gizi, semakin tinggi status gizi produktivitas kerja semakin meningkat. Saran yang dapat diberikan pada perusahaan sebaiknya memberikan fasilitas cek kesahatan berkala minimal satu tahun sekali, sehingga kesehatan pekerja terutama anemia dan status gizi pekerja dapat dipantau. Perlu dilakukan penelitian terkait faktor-faktor lain yang belum diteliti yang dapat mempengaruhi produktivitas kerja seperti asupan makan, gaya hidup, riwayat penyakit dan pendapatan responden.

\section{ACKNOWLEDGEMENT}

Peneliti mengucapkan terima kasih kepada pemilik UD X Sidoarjo yang telah memberikan izin untuk dijadikan tempat penelitian sehingga penelitian ini dapat terlaksana, pekerja wanita UD X Sidoarjo yang sudah ikhlas bersedia menjadi responden dalam penelitian ini.

\section{REFERENSI}

1. Pusat Data dan Informasi Kementrian Kesehatan Republik Indonesia. Situasi Kesehatan Kerja 2015. (2015). Available at:

http://www.depkes.go.id/download.ph p?file=download/pusdatin/\%0Ainfodati n/InfoDatin-2015.pdf.\%0A.

2. International Labour Organization. Keselamatan dan kesehatan kerja.
(2013). Available at: http://www.ilo.org/wcmsp5/groups /public/-asia/-ro-bangkok/-ilojakarta/documents/publication/wcms_2 37650.pdf. (Accessed: 31st January 2018)

3. Sihombing, M. \& Riyadina, W. FaktorFaktor yang Berhubungan dengan Anemia pada Pekerja di Kawasan Industri Pulo Gadung Jakarta. Media Penelit. dan Pengemb. Kesehat. 19, 116-124 (2009).

4. Kementrian Kesehatan. Profil Kesehatan Indonesia Tahun 2013. Jakarta: Kementerian Kesehatan RI (2014). doi:351.770.212 Ind P

5. Citrakesumasari. Anemia Gizi Masalah dan Pencegahannya. (2012).

6. World Health Organization (WHO). Haemoglobin concentrations for the diagnosis of anaemia and assessment of severity. Geneva, Switz. World Heal. Organ. 1-6 (2011). doi:2011

7. Khatun, T. et al. Anemia among Garment Factory Workers in Bangladesh. Middle East J. Sci. Res. 16, 502-507 (2013).

8. Widiastuti, S. \& Dieny, F. F. Faktor determinan produktivitas kerja pada pekerja wanita. J. Gizi Indones. (The Indones. J. Nutr. 4, 28-37 (2016).

9. Anderson, L.W., Krathwohl, D. . Pembelajaran, Pengajaran dan Assessment. (Pustaka Pelajar, 2009).

10. Utami, S. . Status Gizi, Kebugaran Jasmani dan Produktifitas kerja pada tenaga kerja wanit. J. Kesehat. Masy. 8, 113-120 (2013).

11. Syam, F. . Gambaran asupan zat gizi, status gizi, dan produktivitas kerja pada pekerja pabrik kelapa sawit Bagerpang Estate PT.PP.LONSUM 2013. (Universitas Sumatera Utara, 2013).

12. Ariati, N. N. Gizi Dan Produktifitas Kerja. J. Skala Husada 10, 214-218 (2013).

13. Makurat, J. et al. Nutritional and micronutrient status of female workers in a garment factory in Cambodia. Nutrients 8, 1-16 (2016).

14. Aziiza, F. Analisis aktivitas fisik,konsumsi pangan dan status gizi dengan 
produktivitas kerja pekerja wanita di Industri Konveksi. (Institute Pertanian Bogor, 2008).

15. Sinungan. Produktivitas: apa dan bagaimana edisi kedua. (Bumi Aksara, 2005).

16. Anies. Penyakit Akibat Kerja. (Penyakit Akibat Kerja, 2005).

17. Kurtanti. Fisiologi Ginjal dan Sistem Saluran Kemih. (Fakultas Kedokteran Universitas Indonesia, 2009).

18. Murray, R.K., Granner, D.K., Rodwell, V. - Biokimia harper (27 ed.). (Buku Kedokteran EGC, 2009).

19. Tarigan, Y. . Kontribusi proctectivve factors terhadap relsilience wanita dewasa awal penderita sysemic lupus erythematosus di yayasan ' $X$ ' Bandung. (Universitas Kristen Maranatha, 2009).

20. Mantika, A.I., Mulyati, T. Hubungan Asupan Energi, Protein, Zat Besi Dan Aktivitas Fisik Dengan Kadar Hemoglobin Tenaga Kerja Wanita Di Pabrik Pengolahan Rambut Pt. Won Jin Indonesia. J. Nutr. Collage 3, 706-714 (2014).

21. Farikha, R.RP., Ardyanto, D. Produktivitas Pekerja Sorting Dan Packing. Indones. J. Occup. Saf. Heal. 5, 71-80 (2016).

22. Hastuti, D. Hubungan antara lama kerja dengan kelelahan pada pekerja konstruksi di PT. Nusa Raya Cipta Semarang. (Universitas Negeri Semarang, 2015).
23. Anggun. Hubungan Indeks Masa Tubuh dengan dan Kadar Hemoglobin dengan Prduktivitas pada tenaga Kerja Industri Rumah Tangga Garmen. (Universitas Muhammadiyah Surakarta, 2013).

24. Chibriyah, R. Hubungan pola makan dan aktivitas fisik terhadap hadar hemoglobin santriwati pondok pesantren Al-Munawwir Krapyak bantul. (Universitas Aisyiyah Yogyakarta, 2017).

25. Lee, G. . Nutrition and their metabolism. (Saunders, 2008).

26. Hendrayati., Rowa, S. S. \& Mappeboki, S. Gambaran Asupan Zat Gizi , Status Gizi Dan Produktivitas Karyawan Cv . Sinar Matahari Sejahtera di Kota Makassar. Media Gizi Pangan VII, 35-40 (2009).

27. Kusriyana, R., Helmyati, S. \& Budiningsari, R. D. Asupan Zat Gizi, Status Gizi dan Motivasi serta Hubungannya dengan Produktivitas Pekerja Perempuan pada bagian Pencetakan di Pabrik Bakpia Pathuk 25 Yogyakarta. J. Gizi Klin. Indones. 7, 4147 (2010).

28. Astuti, P. Hubungan asupan energi, asupan protein, dan status gizi dengan produktivitas kerja pada tenaga kerja wanita bagian finishing 3 PT Hanil Indonesia Nepen Teras Boyolali. (Universitas Muhammadiyah Surakarta, 2017). 